\title{
Effect of Instructional vs. Authentic Video Materials on Introvert and Extrovert Iranian EFL Learners' Vocabulary Learning
}

\author{
Parya Isazadeh (Corresponding Author) \\ Tabriz Payame Noor University, Iran \\ E-mail: p.eisazadeh@gmail.com \\ Selma Mohammad Zadeh Makui \\ Tabriz Payame Noor University, Iran \\ E-mail: Lvlselma@gmail.com \\ Loghman Ansarian \\ University of Malaya, Iran \\ E-mail: Loghmanelt@siswa.um.my
}

Received: 03-09- 2016

doi:10.7575/aiac.ijels.v.4n.4p.1
Accepted: 18-10-2016

URL: http://dx.doi.org/10.7575/aiac.ijels.v.4n.4p.1
Published: 31-10-2016

\begin{abstract}
The study delved into the effect of instructional video materials vs. authentic video materials on vocabulary learning of extrovert and introvert Iranian EFL learners. To this end, Nelson proficiency test was administered to one hundred eighty $(\mathrm{n}=180)$ language learners. Considering 1 standard deviation above and below the mean score, one hundred twenty three $(n=123)$ language learners were selected for the study. These participants were distributed into 4 experimental groups (with 25 learners) and a control group (with 23 learners). Researcher-made vocabulary pretest and posttest which were designed using the vocabularies from the movies were also administered to the participants. The findings of the study after three weeks of treatment revealed that both authentic video materials and instructional video materials can have positive effect on vocabulary learning of Iranian EFL leaners. This effect, however, is not different among extrovert learners. It was also revealed that introvert EFL learners benefit more from authentic video materials. The findings of the study could be used by material developers or language teachers who may wish to use video materials in their classes.
\end{abstract}

Keywords: Authentic video materials, Instructional video materials, Vocabulary learning, Introversion, Extroversion

\section{Introduction}

To many scholars, vocabulary learning is the core component of second and foreign language learning processes. Wilkins (1972) posited that "....while without grammar very little can be conveyed, without vocabulary nothing can be conveyed" (pp. 111-112). In the same vein, Ghorbani and Rahmandoost (2012) confirmed that it would be difficult for EFL learners to achieve their potentials without having adequate knowledge of vocabulary. It has also been mentioned by Ellis (2003) that knowledge of vocabulary is essential for mastering language skills regardless of its type, either productive or receptive. The aforementioned significance of vocabulary learning can justify the plethora of research conducted in the last 40 years to enhance vocabulary teaching and learning processes.

With the advent of technology, a possible way to enhance EFL learners' knowledge of vocabulary has become audiovisual materials such as videos. Rivers (1981) confirmed that:

all audiovisual materials have positive contributions to language learning as long as they are used at the right time, in the right place. In language learning and teaching processes learners use their eyes as well as their ears; but their eyes are basic in learning. (p.12)

Other scholars such as Tomalin (1993) stated that not all video materials can lead to learning the new language and such materials ought to be interesting and challenging. Kennedy (1996) believed that showing a video to EFL learners is different from watching a film. The former requires teachers' guidance, teaching steps and well-chosen materials.

Another significant issue which has been part of SLA research is language learners' learning styles which refers to the way learners prefer to learn (Wang, Wang \& Huang, 2008). Learning styles play a crucial role within the lives of learners. Once students acknowledge their own learning type, they'll be able to integrate it into their learning method (Folse, 2004). Another advantage of distinguishing learners' learning style is that it assists the teacher in approaching 
them more effectively. The more the learners know of their learning styles, the more they will learn (Biggs, 2001). Moreover, understanding learning styles helps teachers to design lesson plans that match their learners' preferences. This issue is of prime importance to basic learners since they become demotivated more easily. As a result, mismatching ought to be treated with caution because it could cause dropouts (Tuan, 2011).

Dornyei (2005) believed that extroversion and introversion are the personality types that have attracted considerable attention. Brook (2011) represented characteristics of introverts and extroverts. In short, she stated that introverts are more concerned with their own mental life, whereas extroverts prefer to gain gratification from the outside world. Therefore, introverts are less sociable compared to extroverts. Whether being an introvert or an extrovert helps L2 acquisition is not fully understood yet (Brown, 2000). However, those in favor of matched classes, where language learners with the same learning style form the class, believe that introverts can participate as much as extroverts in classes by assigning roles by the teachers' guidance and help (Celce-Murcia, 2004).

It seems that, to the researchers' best knowledge, no prior study has yet dealt with all aforementioned variables (vocabulary learning, video material, introversion and extroversion) in the EFL context of Iran. As a result, this study investigated the effect of two types of video materials, i.e., instructional video material and authentic video material on vocabulary learning of introverted and extroverted EFL learners.

\subsection{Statement of the Problem}

A common problem in the EFL context of Iran, along with many other EFL contexts, is not having access to authentic materials. Not only are most language teachers in Iran non-native speakers, but also language learners do not find the opportunity to practice the newly learned language in the society as of ESL learners. This situation usually causes overlearning instead of acquisition as stated by Krashen (1982). As a result, EFL learners will have to think and stumble to make their sentences and usually monitor their speech for better vocabulary instead of speaking fluently.

Moreover, lack of exposure to authentic materials such as (videos) has caused EFL learners not to be familiar with significant component of vocabulary like pronunciation or parts of speech. Many EFL learners have a cumulative knowledge of vocabulary which is passive and is not at their service when required. Not sure about the pronunciation of the vocabularies, EFL learners lose their confidence in using the words and tend not to use all the words they know (Gumbaridze, 2013).

In addition, in the Iranian EFL context, language classes are usually matched based on EFL learners' gender and age. Other significant factors such as their learning styles is rarely taken into account, whereas research in the field shows that more attention ought to be paid to this issue (Folse, 2004). This problem gains more significance when dealing with teaching and learning materials. Based on the type of materials, i.e., visual, auditory, and kinesthetic, language learners may benefit differently from these materials. Thus, this issue requires special attention. Finally, although quite a number of studies have dealt with the effect of video materials on learning language skills and sub-skills in different parts of the world (Tovmaysan 1997; Woottipong, 2014), research in the EFL context of Iran is scant.

\subsection{Purpose of the Study}

The general purpose of this study is to find out which type of audiovisual materials can have a significant effect on vocabulary learning of Iranian EFL language learners and whether or not this effect is different for introvert and extrovert EFL learners. This broad purpose can be broken down into the followings:

a) to compare the effect of instructional and authentic video materials on vocabulary learning of Iranian EFL learners; and

b) to compare the significance of effect of the instructional and authentic video materials on extroverted and introverted learners.

1.3 Research Questions and Null Hypotheses

In order to pursue the purpose of the study, the answer to the following research questions was sought:

1. What is the effect of instructional videos materials on vocabulary learning of Iranian EFL learners?

2. What is the effect of authentic videos materials on vocabulary learning of Iranian EFL learners?

3. Is there any significant difference between the effect of the instructional and authentic video materials on vocabulary learning of extrovert Iranian EFL learners?

4. Is there any significant difference between the effect of the instructional and authentic video materials on vocabulary learning of introvert Iranian EFL learners?

Hand in hand with the research questions, the following null hypotheses were formed:

$\mathrm{H}_{01}$. Instructional video materials do not have any effect on vocabulary learning of Iranian EFL learners.

$\mathrm{H}_{02}$. Authentic video materials do not have any effect on vocabulary learning of Iranian EFL learners.

$\mathrm{H}_{03}$. There is no significant difference between the effect of instructional and authentic video materials on vocabulary learning of extrovert Iranian EFL learners.

$\mathrm{H}_{04}$. There is no significant difference between the effect of the instructional and authentic video materials on vocabulary learning of introvert Iranian EFL learners. 
There are several reasons why the findings of the study can be significant. First of all, comparing the effect of instructional video materials to authentic video material can help EFL teachers understand which type of video ought to be used in language classes; instead of using both types of video to find out which is more effective empirically by language teachers. This can, in turn, result in more effective communication by language learners. On the other hand, the findings of this study can shed more light on the question of whether or not to use matched classes in terms of learning styles when it comes to using video materials. This issue has not been discussed elsewhere with regard to types of video materials and is worth investigating.

The findings of this study can help EFL teachers provide their language learners with more authentic materials, i.e., audio-visual materials such as videos. As mentioned earlier, a common problem in the EFL context of Iran along with many other EFL contexts is having exposure to authentic English. Based on the results of the study, the most adequate type of video will be suggested at the end of the study.

This study will also remind EFL teachers, material developers and curriculum designers that there are several significant issues that have to be taken into account. First of all, not all teachers' attention ought to be paid to teaching methods and approaches. Materials play a significant role in EFL learners learning process and ought to be taken into account. Secondly, EFL learners are the core of language classes and it is very important to consider their learning styles and preferences as well as other issues.

\section{Review of the Literature}

\subsection{Theoretical Background}

The study for a suitable method to teach vocabulary began in the 1960s and since the mid-1980s, vocabulary learning has been drawing growing attention among ESL researcher. In 1990s, it witnessed a noticeable number of publications leading vocabulary to be a current focus in ESL pedagogy and research (Wei, 2007). Examples of vocabulary learning materials produced based on these research are: dictionaries (either monolingual, or bilingual), and flash cards.

Although quite a number of efforts have been made to find a suitable way to teach vocabulary, this has not always been satisfactory. As a result, a fundamental query was raised to find out why vocabulary learning is such an uncooperative issue and what method could best serve the purpose of teaching vocabulary. One possible answer to the problem of vocabulary was applying teaching vocabulary learning strategies. Research into language learning strategies reveals that vocabulary can be taught in different ways each of which with its own merits and demerits.

Vocabulary learning is of different types. Two main types of vocabulary learning 'incidental learning' as opposed to 'direct intentional. As stated by Nation (2001) extensive reading is the primary cause for incidental vocabulary learning. On the other hand. In addition, in case students want to learn vocabulary intentionally, they should follow certain strategies. So far, the researchers in the filed have not agreed on which type of vocabulary teaching approaches, either contextualized or de-contextualized" is the most suitable to be used. Some research, however, such as Oxford and Scarcella (1994) believe that vocabulary learning in a decontextualized setting is learning from the word list and not effective.

\subsection{Using video to learn Vocabulary}

Traditionally, 2 main uses of video are distinguished: instructional video, specifically created to show foreign languages, and authentic video materials, like films, TV series, commercials, etc., originally created for native speakers of the language. Making use of authentic materials in language classes can be effective, though dealing with it is tougher than the instructional video materials. Indeed, the language learners are exposed to a greater source of input which is more valid.

There is a comprehensible downside in the use of authentic videos within the foreign language classes: they reveal real language which is not ranked nor simplified, and spoken at a traditional speed. That's why the video clips got to be ready ahead, amid the acceptable pre-viewing, viewing and post-viewing activities (some samples of these activities are provided at the tip of this paper). The supply of the clips is sitcoms, soaps, series, films, short films, TV commercials, or documentaries. we have a tendency to square measure talking concerning clips as a result of the video sequences got to be short (Stempleski \& Tomalin, 1990), around 2 or 3 minutes long, to possess time to take advantage of all their contents at school, using the acceptable ad-hoc activities simply mentioned. Finally, if we wish these clips to achieve success as some extent of departure to develop foreign language skills, it's necessary for them to be clear, freelance, self-contained, and fascinating enough to encourage students and stimulate discussion. Students of all levels will like the utilization of video, since there square measure continuously easier video sequences, spoken at a slower rate, that may match lower level students' wants. Besides, authentic video has a comprehensible advantage over standard audio tapes (that square measure generally terribly hard-to-please and will harm the students' confidence): the visual dimension that produces understanding easier through gestures and context (Talaván, 2007).

\subsection{Learning Styles}

Different terms have been utilized in literature like learning type, psychological feature style, and sensory preference. A number of these terms, in some instances, are used interchangeably, whereas in alternative occasions they out to be differentiated (Cassidy, 2004). Learning styles are outlined by James and Gardner (1995) as "the advanced manner 
within which, and conditions below that, learners most effectively understand, process, store, and recall what they're trying to learn" (p.20), whereas psychological styles are outlined as "an individuals' natural, habitual, and most popular means (s) of engrossing, process and holding new info and skills" (Reid, 1995, p. viii). Mortimore (2008) made a distinction between learning styles and psychological styles. He indicates that learning styles are seen a lot in terms of the methods that learners use to handle learning, and are thought of to be less stable. On the opposite hand, psychological styles are comparatively stable. Thus, learning styles, as opposition learner preferences, are often stretched with the passage of your time. It should be noted that the difference between psychological style and learning style isn't crystal clear as some authors use them interchangeably (Williamson \& Watson, 2006).

\subsection{Classification of Learning Styles}

There are three different classifications of learning styles: the first type is psychological feature, the second is temperament, and the third is sensory. The first group consists of analytical/ international, field dependent/ field freelance, impulsive/ reflective learning styles. The second group (behavioral) can be subdivided into extroversion/introversion, random-intuitive/concrete serial, and closure-oriented/ open destined. Finally, 3 different types of sensory learning styles are: visual, tactile/kinesthetic and audile (Oxford, 1990).

Introversion and extroversion, as posited by McCrae and Costa (1987) are two extremes of a continuum. Although extroverts are more assertive and sociable, and as a result; more successful at leadership activities, introverts are more timid and prefer individual activities. As stated by Perkins (2014), individuals are not either extrovert or introvert. Indeed, every individual may be a balance of the two features of a varying degree of it. In order to find out which tendency exists more in an individual, Eysenck personality inventory (EPI) is usually used. The test measures two pervasive, independent dimensions of personality, Extraversion-Introversion and Neuroticism-Stability, which account for most of the variance in the personality domain. Each form contains 57 "Yes-No" items with no repetition of items. The inclusion of a falsification scale provides for the detection of response distortion.

Learners learn more, if their learning styles match the format of their instruction. For instance, a visual learner could learn better, once information is transferred to him/ her visually. This idea is the premise of the "matching hypothesis" (Pashler et al, 2009, p.108). Conversely, a different learning style could leave negative impacts on the learners. So far there's no valid proof, for instance, that learning style is better than the other. In keeping with Ellis (2005), Learners manifest completely different learning styles, however; it's not nevertheless clear whether or not some designs end in quicker and more learning than others. Despite the fact that, the models of learning style will still shed some light on sophisticated method of learning.

The effect of visual materials on L2 vocabulary learning of male and female Iranian EFL learners was sought by Zarei and Gilanian (2013). To this end, a movie was shown to different participants with different combinations of multimedia. One of the cohorts saw the video with audio and caption, the other only with audio and the thier group only with caption. The study revealed that not only the presence of caption, but also audio can have positive effect on learning vocabulary of Iranian EFL learners at Qazvin University in Iran. The main difference between the current study and the one carried by Zarei and Gilanian (2013) is that the effect of different types of video materials was sought in the current study.

A different study was carried out by Hashemi and Pour gharib (2014) who investigated how subtitles and audio can affect vocabulary learning of Iranian EFL learners. The study, however, only dealt with female learners at intermediate level. The findings of the study revealed that the combination of subtitles and audio can resut in better understanding of the vocabulary as the experimental group outperformed the control group.

\section{Method}

This study made use of a randomized procedure in selecting the participants. As stated by Mackey and Gass (2015) experimental studies with a randomized procedure in selecting the participants are true experimental. The independent variables in this study are the effect of instructional video materials and authentic video materials. The dependent variable in the study is vocabulary learning and the moderator variables are cognitive learning styles, i.e., introversion and extroversion.

\subsection{Participants}

A cohort of 180 Iranian EFL learners studying at Goldis Language Institute formed the participants for this study. Nelson proficiency test was administered to the participants to homogenize them based on their proficiency level. Considering 1 standard deviation above and below the mean score of the participants on the test one hundred ( $\mathrm{n}=123$ ) EFL learners were selected as intermediate EFL learners to pursue the purpose of the study. Next, Eysenck Personality Inventory (EPI) was administered to the selected participants to categorize them into extrovert and introvert EFL learners. After that, the participants formed 5 groups, 4 experimental groups; namely, experimental groups 1 to 4 with 25 participants in each group, and a control group with 23 learners. Authentic video materials were shown to experimental groups 1 and 2, and instructional video materials were shown to experimental groups 3 and 4 . The participants for this study were both male and female learners. Azari Turkish and Persian were the languages they could already speak as the mother tongue. In addition, it should be mentioned that all participants were adult learners. 
To select one hundred $(N=123)$ intermediate participants for the study, Nelson vocabulary test was administered to 150 English language learners $(N=180)$. The test had 38 multiple-choice vocabulary items and by assigning 1 point to correct answers and 0 to the wrong answers, the test was scored. Then the statistics were done. Considering Table 1, the mean of the scores was $(M=21.69)$ and the standard deviation was $(S D=38.389)$.

Table 1. Descriptive Statistics, Nelson Vocabulary Test

\begin{tabular}{lcccc}
\hline & $\mathrm{N}$ & Mean & Std. Deviation & Variance \\
\hline Nelson Vocabulary Test & 180 & 21.69 & 6.196 & 38.389 \\
\hline
\end{tabular}

The acceptable range of the scores for this study was between the mean and one standard deviation below (-1SD) and one standard deviation above $(+1 S D)$ the mean, $(21.69-6.196=15.49$ and $21.69+6.196=27.89)$. Accordingly, 123 intermediate participants, whose scores stood between 16 and 28, were selected. Based on the results of this test and Eysenck Personality Inventory the participants were distributed into four different groups.

\subsection{Instruments and Materials}

Nelson language proficiency test was given to the population in order to homogenize them based on their level of proficiency; namely, intermediate. Nelson test is a fifty item test. The test consists of cloze tests, and multiple questions with the focus on grammar and choice of words.

The Eysenck Personality Inventory (EPI) was used in this study to select introvert and extrovert EFL learners. The test measures two pervasive, independent dimensions of personality, Extraversion-Introversion and Neuroticism-Stability, which account for most of the variance in the personality domain. Each form contains 57 "Yes-No" items with no repetition of items. The inclusion of a falsification scale provides for the detection of response distortion.

A Researcher-made Pretest containing 30 multiple-choice items was designed by the researcher to be used as the pretest. The vocabularies were selected from the video material which was shown to the participants. The researchermade pretest was piloted using a different group of EFL learners. Item analysis was run to gauge item facility (IF) and item discrimination (ID) for the test. The reliability of the test was also gauged using Crombach alpha formula.

A Researcher-made Posttest containing 30 multiple-choice items was designed by the researcher to be used as the posttest. The vocabulary was selected from the video material which were shown to the EFL learners. The researchermade posttest was piloted using a different group of EFL learners. Item analysis was run to gauge item facility (IF) and item discrimination (ID) for the test. The reliability of the test will also be gauged using Crombach alpha formula.

Both authentic and instructional video materials were used in this study. As stated by Mousavi and Iravani (2010), authentic video material show daily conversation with a normal fluency rate. The conversations are not standardized in terms of structure, vocabulary, speech rate, etc. On the other hand, instructional video material aim at teaching the language. As a result, the conversations are standardized, repeat the structures and vocabulary and have a lower speech rate. In order to conduct this study both authentic and instructional video materials were selected from POD English Series available on www.youtube.com.

\subsection{Procedure}

Having selected the participants for this study, all participants went through the researcher-made pretest. The four experimental groups also went through 2 types of treatments. Experimental groups 1 and 2 went through authentic video materials instruction, and experimental groups 3 and 4 went through instructional video materials instruction. The participants in the control group did not receive any particular treatment. The intended vocabularies were taught to them by the teacher through an input-based instruction by using mechanical drills. The treatment took 10 sessions and each session was 45 minutes. After the course of treatment, all participants in all groups took the researcher-made posttest. The results of the pretest and the posttest was compared in order to answer the research questions. Every session each class was divided into 3 main sections: 1) pre-movie activities, in which the teacher will activate the participants' schemata by asking relevant questions about the movie topic. 2) Movie activities, in which the movie was watched, the participants could take notes if they wished. 3) post-movie activities, in which a few questions were asked about the movie. New vocabularies were introduced and practiced and finally there was a free discussion about the movie.

\subsection{Data Analysis}

SPSS (version 22) is the main software used in the study. Inferential statistics such as ANOVA and independent samples t-test were used to find the answer to the research questions.

\section{Results}

This section consists of two main parts. The first presents the results of normality and reliability tests. In the second part, the results of the study are reported and interpreted. 
Nelson language proficiency test was administered to 150 language learners at the intermediate level. The distribution of data on the test was checked by considering rations of skewness and kurtosis. As can be seen in Table 2, the score revealed normal distribution as the ratios of skewness and kurtosis were within the range of +/_ 1.96 (Strevens, 2009 ). Ratios of skewness and kurtosis of the pretest and posttest score are also shown in Table 2.

Table 2. Test of Normality, All Tests

\begin{tabular}{lcccccc}
\hline & & \multicolumn{2}{c}{ Skewness } & \multicolumn{2}{c}{ Kurtosis } \\
\cline { 3 - 7 } & & Statistic & Statistic & Std. Error & Statistic & Std. Error \\
\hline Nelson Vocabulary Test & & 150 & .289 & .198 & -.339 & .394 \\
\hline & Group 1 & 25 & -.104 & .464 & -.221 & .902 \\
Vocabulary Pretest & Group 2 & 25 & .218 & .464 & -.924 & .902 \\
& Group 3 & 25 & .076 & .464 & -.873 & .902 \\
& Group 4 & 25 & -.195 & .464 & -.981 & .902 \\
\hline \multirow{5}{*}{ Vocabulary Posttest } & Control & 23 & .265 & .464 & -.654 & .902 \\
\hline & Group 1 & 25 & .401 & .464 & -.359 & .902 \\
& Group 2 & 25 & .262 & .464 & -.233 & .902 \\
& Group 3 & 25 & .425 & .464 & .414 & .902 \\
& Group 4 & 25 & .380 & .464 & -.430 & .902 \\
& Control & 23 & .543 & .464 & .342 & .902 \\
\hline
\end{tabular}

The reliability of the homogeneity test score was measured using Cronbach's alpha $(\alpha=.79)$, which was acceptable. Item analysis was also done for evaluating test items. Results showed that the item facility of the test items was between 0.5 and 0.8 and discrimination indices were between 0.25 and $0.5,(0.5<I F<0.8$ and $0.25<D I<0.5)$ which are in the acceptable ranges. Then, all the items of researcher-made test can be considered as good items. It means that the test items are not too easy or too hard and the test has the power to discriminate between the better and poorer test takers.

A researcher-made vocabulary pretest was administered to be used as a basis for further comparison. The scores were compared by using one-way ANOVA test. Some other tests (normality and Levene's test) were done to check that the data meet the assumptions for applying the ANOVA test. Descriptive statistics of five different groups (Table 3) indicated that the mean score for group $1(N=25)$ was $(M=21.60)$ and $(S D=2.972)$. For group $2(N=25)$ the mean was $(M=21.00)$ and $(S D=3.742)$. For group $3(N=25)$ the mean was $(M=22.04)$ and $(S D=2.715)$ and for group 4 $(N=25)$ the mean was $(M=20.76)$ and $(S D=2.876)$. Finally, for the control group $(N=23),(M=21.02, S D=2.86)$.

Table 3. Descriptive Statistics, Pretest of vocabulary

\begin{tabular}{lllcc}
\hline & $\mathrm{N}$ & Mean & Std. Deviation & Variance \\
\hline Group1 (authentic-video / extrovert) & 25 & 21.60 & 2.972 & 8.833 \\
Group2 (authentic-video / introvert) & 25 & 21.00 & 3.742 & 14.000 \\
Group3 (instructional-video / extrovert ) & 25 & 22.04 & 2.715 & 7.373 \\
Group4 (instructional video / extrovert) & 25 & 20.76 & 2.876 & 8.273 \\
Group 5(Control) & 23 & 21.02 & 2.865 & 9.537 \\
\hline
\end{tabular}

According to Table 2, distribution of the scores for different groups was normal and the first assumption for applying the ANOVA test was met. By applying Levene's test, the homogeneity of variances of four groups was checked and the amount of significance in Table $4(\mathrm{Sig}=0.146)$, which is greater than 0.05 , shows that the assumption of homogeneity of variances was also met.

Table 4. Homogeneity of Variances, Pretest of Vocabulary

\begin{tabular}{cccc}
\hline Levene's Statistic & df1 & df2 & Sig. \\
\hline 1.837 & 3 & 96 & .146 \\
\hline
\end{tabular}


Then the ANOVA test was carried out. According to Table 5, one-way ANOVA test, the $F$ value $\left(F_{3,96}=0.874, S i g=\right.$ $0.457)$ indicated that there was not a statistically significant difference among the groups and they were homogenous in terms of vocabulary proficiency.

Table 5. ANOVA Results for Pretest of Vocabulary

\begin{tabular}{lccccc}
\hline & Sum of Squares & df & Mean Square & F & Sig. \\
\hline Between Groups & 25.230 & 3 & 8.410 & .874 & .457 \\
Within Groups & 923.520 & 96 & 9.620 & & \\
Total & 948.750 & 99 & & & \\
\hline
\end{tabular}

\subsection{Effect of instructional video materials on vocabulary learning}

To test the hypotheses, the results of researcher-made vocabulary posttest were analyzed. Descriptive statistics is shown in Table 6.

Table 6. Descriptive Statistics Results for Posttest of Vocabulary

\begin{tabular}{llccc}
\hline & $\mathrm{N}$ & Mean & Std. Deviation & Variance \\
\hline Group1 (authentic-video / extrovert) & 25 & 20.44 & 3.097 & 9.590 \\
Group2 (authentic-video / introvert) & 25 & 19.88 & 2.906 & 8.443 \\
Group3 (instructional-video / extrovert ) & 25 & 17.48 & 2.786 & 7.760 \\
Group4 (instructional video / extrovert) & 25 & 18.24 & 2.773 & 7.690 \\
Group 5(Control) & 23 & 17.40 & 2.778 & 7.715 \\
\hline
\end{tabular}

The first research question was, "What is the effect of instructional videos materials on vocabulary learning of Iranian EFL learners?'

Performing an independent samples t-test, the scores of experimental groups 3 and 4 (considered as 1 group) was compared to the control group. Table 7 shows descriptive statistics of these two groups.

Table 7. Descriptive Statistics, Posttest of Vocabulary, Experimental and Control Groups

\begin{tabular}{llccc}
\hline & $\mathrm{N}$ & Mean & Std. Deviation & Variance \\
\hline Experimental Groups (Group1 \& Group2) & 50 & 20.72 & 3.411 & 11.634 \\
Control Groups & 23 & 17.40 & 2.778 & 7.715 \\
\hline
\end{tabular}

As shown in Table 8, the scores were significantly higher for experimental groups (combination of groups 3 and 4 ) ( $M$ $=20.72, S D=3.411)$ than for control group $(M=17.40, S D=2.778), \mathrm{t}_{(48)}=3.988, p<.0005$. As a result, the first null hypothesis, stating that instructional video materials do not have any significant effect on vocabulary learning of Iranian EFL learners, was rejected.

Table 8. T-Test Results for Vocabulary Posttest (Experimental vs. Control Groups, Instructional Video Materials)

\begin{tabular}{|c|c|c|c|c|c|c|c|c|c|}
\hline & \multicolumn{4}{|c|}{ Levene's Test } & \multicolumn{3}{|c|}{ t-test for Equality of Means } & & \\
\hline & \multirow[b]{2}{*}{$\mathrm{F}$} & \multirow[b]{2}{*}{ Sig. } & \multirow[b]{2}{*}{$\mathrm{t}$} & \multirow[b]{2}{*}{ df } & \multirow{2}{*}{$\begin{array}{c}\text { Sig. } \\
\text { (2-tailed) }\end{array}$} & \multirow{2}{*}{$\begin{array}{c}\text { Mean } \\
\text { Difference }\end{array}$} & \multirow{2}{*}{$\begin{array}{l}\text { Std. Error } \\
\text { Difference }\end{array}$} & \multicolumn{2}{|c|}{$\begin{array}{l}95 \% \text { CI of the } \\
\text { Difference }\end{array}$} \\
\hline & & & & & & & & Lower & Upper \\
\hline Equal variances assumed & .431 & .513 & 3.988 & 48 & .000 & 3.320 & .577 & 1.156 & 3.444 \\
\hline
\end{tabular}

\subsection{Effect of authentic videos materials on vocabulary learning}

The second research question was, 'What is the effect of authentic videos materials on vocabulary learning of Iranian EFL learners?' To answer the research question, the scores of experimental group 1 and 2 (considered as 1 group), and the control group were compared. As displayed in Table 9, the experimental group (combination of group 1 and 2) ( $M$ $=20.44, S D=3.097)$ outperformed the control group $(M=17.40, S D=2.778), \mathrm{t}_{(48)}=3.553, p=.001$. As a result, the 
second null hypothesis which stated that authentic video materials do not have any significant effect on vocabulary learning of Iranian EFL learners was rejected.

Table 9. Independent Samples T-Test, Posttest of Vocabulary, Authentic Video Materials

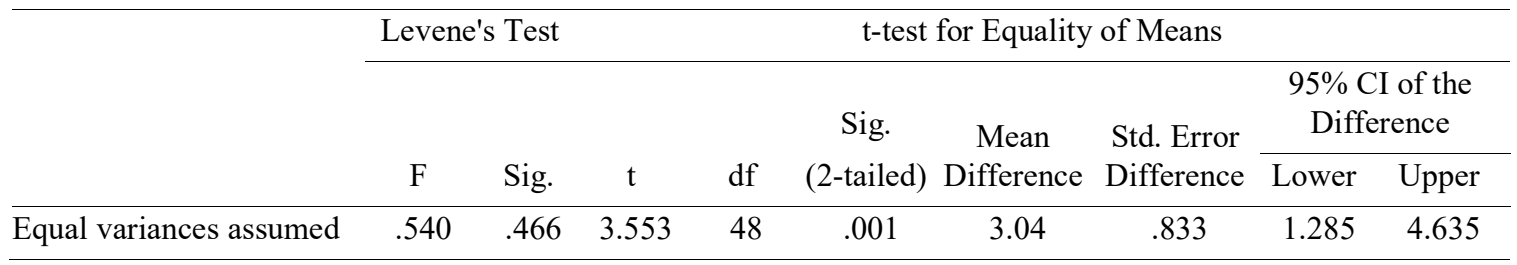

Thus, it was concluded that the experimental group performed better than the control group.

4.4 Effect of instructional and authentic video materials on vocabulary learning of extrovert learners

The third research question was, 'Is there any significant difference between the effect of the instructional and authentic video materials on vocabulary learning of extrovert Iranian EFL learners?'

To answer the question, the scores of group 1 and group 3 were compared. According to Table 10, instructional experimental group (group 3) $(M=20.44, S D=3.097)$ and authentic-video extrovert group (group 1) $(M=19.88, S D=$ 2.906) performed more or less the same and mean difference between the two groups was not statistically significant, $t$ ${ }_{(48)}=6.59, p=.513>.05$. So the third null hypothesis was rejected.

Table 10. Independent Samples T-Test, Posttest of Vocabulary, Experimental Groups

\begin{tabular}{|c|c|c|c|c|c|c|c|c|c|}
\hline & \multicolumn{4}{|c|}{ Levene's Test } & \multicolumn{3}{|c|}{ t-test for Equality of Means } & & \\
\hline & \multirow[b]{2}{*}{$\mathrm{F}$} & \multirow[b]{2}{*}{ Sig. } & \multirow[b]{2}{*}{$\mathrm{t}$} & \multirow[b]{2}{*}{$\mathrm{df}$} & \multirow{2}{*}{$\begin{array}{c}\text { Sig. } \\
\text { (2-tailed) }\end{array}$} & \multirow{2}{*}{$\begin{array}{c}\text { Mean } \\
\text { Difference }\end{array}$} & \multirow{2}{*}{$\begin{array}{l}\text { Std. Error } \\
\text { Difference }\end{array}$} & \multicolumn{2}{|c|}{$\begin{array}{l}95 \% \text { CI of the } \\
\text { Difference }\end{array}$} \\
\hline & & & & & & & & Lower & Upper \\
\hline $\begin{array}{l}\text { Equal variances } \\
\text { assumed }\end{array}$ & .343 & .561 & .659 & 48 & .513 & .560 & .849 & -1.148 & 2.268 \\
\hline
\end{tabular}

\subsection{Effect of instructional and authentic video materials on vocabulary learning of introvert learners}

The final research question was, 'Is there any significant difference between the effect of the instructional and authentic video materials on vocabulary learning of introvert Iranian EFL learners?'

As the previous question, to answer the fourth question of the study, the scores of group 2 and group 4 were compared. According to Table 11, independent samples t-test results shows that (Group2) authentic-video introvert group ( $M=$ $19.88, S D=2.906)$ performed better than the instructional-video introvert group (group 4$)(M=18.24, S D=2.773), \mathrm{t}$ $(48)=2.042, p=.047$. AS a result, the fourth null hypothesis was rejected.

Table 11. Independent Samples T-Test, Posttest of vocabulary, introvert Groups

\begin{tabular}{|c|c|c|c|c|c|c|c|c|c|}
\hline & \multicolumn{4}{|c|}{ Levene's Test } & \multicolumn{3}{|c|}{ t-test for Equality of Means } & & \\
\hline & \multirow[b]{2}{*}{$\mathrm{F}$} & \multirow[b]{2}{*}{ Sig. } & \multirow[b]{2}{*}{$\mathrm{t}$} & \multirow[b]{2}{*}{ df } & \multirow{2}{*}{$\begin{array}{c}\text { Sig. } \\
\text { (2-tailed) }\end{array}$} & \multirow{2}{*}{$\begin{array}{c}\text { Mean } \\
\text { Difference }\end{array}$} & \multirow{2}{*}{$\begin{array}{l}\text { Std. Error } \\
\text { Difference }\end{array}$} & \multicolumn{2}{|c|}{$\begin{array}{l}95 \% \text { CI of the } \\
\text { Difference }\end{array}$} \\
\hline & & & & & & & & Lower & Upper \\
\hline Equal variances assumed & .001 & .974 & 2.042 & 48 & .047 & 1.640 & .803 & .025 & 3.255 \\
\hline
\end{tabular}

\section{Discussion}

The results of the data analysis revealed that both authentic video materials and instructional video materials can have a positive effect on vocabulary learning of Iranian EFL leaners. This effect, however, is not different among introvert and extrovert learners; meaning that the comparative effect of instructional vs. authentic video materials on vocabulary learning of both introvert and extrovert Iranian EFL learners, no significant difference was observed.

Brown (2000) stated that the issue that whether introversion or extroversion among participants can affect L2 acquisition is controversial. In line with Brown (2000) the findings of this study revealed that these two learning styles cannot be considered as a factor in learning vocabulary among Iranian EFL learners. 
Kim (2000) believed that authentic materials can have the utmost effect on L2 acquisition of intermediate learners and above. Indeed, it would be hard for learners at early stages of 12 acquisition to benefit from authentic materials. The current study not only made use of authentic video materials, but also compared its effect with instructional materials on vocabulary learning of Iranian EFL learners. The findings revealed that authentic video materials can have a positive effect on vocabulary learning of Iranian EFL learners (Research question 1). As the results present, it can be stated that the findings of the studies are congruent.

Guariento and Morley (2001) believed one should be careful about using authentic materials in language classes as they can be demotivating for novice language learners. As Guariento and Morley (2001) did not have their focus on language learners at other proficiency learners, the findings of the current study can complete their conclusion by stating that more proficient language learners can make use of authentic video materials.

Cornish (1994) believed that using video materials in language classes is a very advantageous for language learners, especially with regard to their listening skill. The current study revealed that video materials can have positive effect on L2 acquisition, however, their effect was sought on the vocabulary sub-skill rather than the listening skill.

\section{Conclusion}

Based on the findings of the study, it can be concluded that different types of video materials can be considered by material developers and teachers who wish to use them in language classes. In addition, there is no need to separate language learners into matched classes in terms of introversion and extroversion while showing movies to them 9 as no significant difference was observed between these two groups in this study. The findings of this study could be of interest to material developers who wish to prepare video materials for language classes, and policy makers who may want to decide whether language classes should be matched based on language learners' learning styles.

\section{References}

Biggs, J. (2001). The reflective institution: Assuring and enhancing the quality of teaching and learning. Higher Education, 41(3), 221-238.

Brook, J. (2011). The affordances of YouTube for language learning and teaching. Hawaii Pacific University TESOL Working Paper Series, 9(1), 2.

Brown, H. D. (2000). Principles of language teaching and learning. White Plains, NY: Longman.

Cassidy, S. (2004). Learning styles: An overview of theories, models, and measures. Educational Psychology, 24(4), 419-444.

Celce-Murcia, M. (2004). Teaching speaking. Cambridge: Cambridge University Press.

Cornish, S. (1994). Video in the TESOL Classroom, in Erica Garvey's Reading text for language teaching methodologies, (p. 2) NCELTR, Macquarie University, Sydney- Australia.

Dornyei, Z. (2005). The psychology of the language learner. US: Lawrence Erlbaum Associates.

Ellis, N. C. (1995). The psychology of foreign language vocabulary acquisition: Implications for CALL. Computer Assisted Language Learning, 8(2-3), 103-128.

Ellis, R. (2003). Task-based language learning and teaching. Oxford University Press.

Ellis, R. (2005). Principles of instructed language learning. System, 33(2), 209-224.

Folse, K. S. (2004). Vocabulary myths: Applying second language research to classroom teaching (No. Sirsi) i9780472030293). Ann Arbor, MI: University of Michigan Press.

Gharib, A., Vojdanifard, L., Noroozi Pesyan, N., Hashemi Pour Khorasani, B. R., \& Jahangir, M. (2014). Catalytic synthesis of bis-2, 3-dihydroquinazolin-4 (1H)-ones and 2, 3-dihydroquinazolin-4 (1H)-ones derivatives with the aid of silica-supported Preyssler nanoparticles (SPNP). Bulgarian Chemical Communications, 46(4), 667-679.

Ghorbani, M. R., \& Rahmandoost, M. (2012). Higher task-induced involvement load enhances students' EFL vocabulary learning. Journal of Language Teaching and Research, 3(6), 1202-1207.

Guariento, W. and Morley, J. (2001), Text and Text Authenticity in the EFL classroom, ELT Journal, 55(4), $347-351$.

Gumbaridze, J. (2013). Error correction in EFL speaking classrooms. Procedia-Social and Behavioral Sciences, 70 , 1660-1663.

James, W. B., \& Gardner, D. L. (1995). Learning styles: Implications for distance learning. New Directions for Adult and Continuing Education, 67, 19-31.

Kennedy, C., \& Kennedy, J. (1996). Teacher attitudes and change implementation. System, 24(3), 351-360.

Kim, D. (2000). A qualitative approach to the authenticity in the foreign language classroom: A study of university students learning English in Korea. Texas Papers in Foreign Language Education, 5(1), 189-205 
Krashen, S. (1982). Principles and practice in second language acquisition.

Mackey, A., \& Gass, S. M. (2015). Second language research: Methodology and design. Routledge.

McCrae, R. R., \& Costa, P. T. (1987). Validation of the five-factor model of personality across instruments and observers. Journal of Personality and Social Psychology, 52(1), 81.

Mousavi, S. A., \& Iravani, H. (2012). The effect of authentic versus non-authentic aural materials on EFL learners' listening comprehension. English Language and Literature Studies, 2(1), 21.

Mortimore, T. (2008). Dyslexia and learning style: a practitioner's handbook. John Wiley \& Sons.

Nation, I. S. (2001). Learning vocabulary in another language. Ernst Klett Sprachen.

Oxford, R. L. (1990). Language learning strategies: What every teacher should know. Newbury House Publishers.

Oxford, R. L., \& Scarcella, R. C. (1994). Second language vocabulary learning among adults: State of the art in vocabulary instruction. System, 22(2), 231-243.

Pashler, H., McDaniel, M., Rohrer, D., \& Bjork, R. (2009). Learning styles: Concepts and evidence. Psychological Science in the Public Interest, 9(3), 105-119.

Perkins, J. N. (2014). Targeting Extraversion and Introversion in the Workplace. Western Undergraduate Psychology Journal, 2(1), 11.

Reid, J. M. (1995). Learning Styles in the ESL/EFL Classroom. Florence, KY: Heinle \& Heinle Publishers.

Rivers, W. M. (1981). Teaching foreign-language skills. Chicago, IL: University of Chicago Press.

Stempleski, S., \& Tomalin, B. (1990). Video in action. Prentice-Hall.

Talaván, N. (2007). Learning vocabulary through authentic video and subtitles. Tesol-Spain Newsletter, 31, 5-8.

Tomalin, B. (1992). Teaching young children with video. In Stempleski, S. \& Arcario, P. (Eds.) Video in second language teaching: Using, selecting, and producing for the classroom, (47-55).

Tuan, L. T. (2011). An empirical research on self-learning vocabulary. Theory and Practice in Language Studies, 1(12), $1688-1695$

Wang, T. I., Wang, K. T., \& Huang, Y. M. (2008). Using a style-based ant colony system for adaptive learning. Expert Systems with Applications, 34(4), 2449-2464.

Wei, M. (2007). An examination of vocabulary learning of college-level learners of English in China. Asian EFL Journal, 9(2), 93-114.

Williamson, M. F., \& Watson, R. L. (2006). Learning styles research: Understanding how teaching should be impacted by the way learners learn. Christian Education Journal, 3(1), 27.

Wilkins, D. A. (1972). Linguistics in language teaching. E. Arnold,

Woottipong, K. (2014). Effect of using video materials in the teaching of listening skills for university students. International Journal of Linguistics, 6(4), 200.

Zarei, A. A., \& Gilanian, M. (2013). The effect of multimedia modes on L2 vocabulary learning. International Journal of Management and Humanity Sciences, 2, 1011-1020. 